\title{
Computer-assisted Translation Teaching Based on Constructivist Theory
}

\author{
Jinling Liu, Nan Li, Haibo Sun \\ Jilin University \\ Heping Campus \\ Changchun, China
}

\begin{abstract}
According to the constructivist theory, with the assistance of teachers and peers, students could construct their knowledge by using learning materials and information resources. Previously, there is few study on teaching translation under the multi-media and the network environment based on the constructivist theory. Therefore, with the analysis of the result of multi-media and the network application in translation teaching process and the computer assisted translation teaching problems, the paper identifies some appropriate solutions and in the meanwhile constructs a way of professional translation teaching.
\end{abstract}

Keywords-constructivist theory, multi-media and network environment, translation teaching

\section{INTRODUCTION}

With the development of the information technology, it is necessary for teachers to use the multi-media and the network to solve the serious problems that appear among students. The multi-media and the network teaching means play an important role in the translation course. Concerning their advantages, it is an effective way for teachers to create the vivid environment. By using the network, teachers and students could use the internet resources to find the information they need in the study of the translation course. On the other hand, students could communicate with each other, and they also could interact with the teachers conveniently. However, there still exist some limitations and problems in computer-assisted translation teaching. Therefore, it is necessary to do some study further.

\section{LITERATURE REVIEW}

\section{A. Translation Teaching Based on Constructivist Theory}

Constructivist theory was proposed by the psychologist Piaget in 1966. Later, many scholars developed the constructivism from different aspects. According to Constructivism, learning is the process in which students actively construct their knowledge instead of receiving translation knowledge passively. The constructivism is student-centered, the teacher is the facilitator, initiator and organizer, and the students could use many kinds of ways to construct their knowledge.

In translation teaching, teachers are the guider who instructs the students to involve actively in the translation courses. The interaction instruction teaching mode paid much attention to the communication and interaction not only between the students and the teachers, but also among students themselves. In 2011, Huang $\mathrm{Li}$ pointed that students were not the container of the translation knowledge and the translation skill any more, but active learners. Students could combine the translation knowledge with his own knowledge that has already existed in his brain. Through the interaction and communication, students cooperated with each other to process the translation knowledge. Thus they could assimilate the translation knowledge into the real environment to construct new translation knowledge.

\section{B. The Present Study of Multimedia and Network Application to Translation Teaching}

In the age of information, computer-assisted language teaching is more and more applied in the national college English teaching. However, CAT-related courses are not included in the curricula of language or translation teaching in major universities in China. Gu Peiya studied the effectiveness of this new teaching mode under the computer -assisted environment to investigate five characteristics of constructivist learning and she also discussed the impact on the traditional teaching approaches and challenges to Chinese EFL teachers today. Xu Bin emphasized the necessity of such course and the impact CAT brought about to the translation teaching and pointed out that such course can help students to develop their abilities and meet the demands of high-quality translators. Shi Xinmin and Xiao Weiqin illustrated the advantages and necessity of translation teaching with information technology.

Based on the previous studies, it is admitted that with the development of teaching technology, language learning and teaching under the multimedia and network environment has made great progress. As we all known that, translation teaching is considered as a way to improve the ability of application of language. Most studies focus on the feasibility and rationalization of the translation teaching based on the constructive theory under the multimedia and the network. However, few researchers have done the research on its effectiveness. Therefore, it is necessary to do such kind of research among teachers and students to improve the quality of translation teaching

\section{METHODOLOGY}

Methodologically speaking, this paper adopts descriptive and quantitative way of analysis. The research aims to investigate the situation of the translation teaching under the 
multimedia and the network environment based on the six elements including the role of the teachers and students, teaching content, environment, instruments and the assessments. It also plans to find out the existing problems of such translation teaching in some University of Jilin province, and also the impact of the application of this new teaching mode.

\section{A. Subjects}

The subjects are students from some university of Jilin province. There are altogether 80 subjects who are English majors involved in this investigation. The students belong to different classes with the same English teachers.

\section{B. Experimental Teaching Materials}

English-Chinese Contrast and Translation was employed as the teaching material in this study and was made into PPT when being used in the translation class. The material was taught in the first semester in 2012, four hours every week, which lasted about 16 weeks. Students learned the translation materials in the traditional class for two hours, and another two hours under the multimedia environment. As for the homework, teachers left students assignments for every two weeks and the homework was sent to the teacher through the internet and then the teacher gave the immediate feedback by emails.

\section{Questionaire}

In this study, the writer used the questionnaire to investigate the teaching translation under the multimedia and the network environment based on the six elements. The questionnaire, which are designed according to the constructivist theory, consists 25 English choice questions. The questions are easy to understand so that students could finish them without any difficulty. In the process of filling out the questionnaire, the students are informed to write carefully to make sure the answers could be faithful and honest.

\section{Data Collection}

The questionnaires were filled out under the teacher's supervision in order to write confidentially and faithfully. Altogether 80 questionnaires were distributed, with 80 got back. All questionnaires returned are valid.

\section{CONSTRUCTIVIST PERSPECTIVES OF TRANSLATION LEARNING AND TEACHING UNDER MULTIMEDIA AND NETWORK ENVIRONMENT}

\section{A. Teachers in Translation Teaching Process}

The constructivists believe that teachers play an important part as the organizer, guider and facilitator in teaching activities. Students show their initiative and originality through the interaction with the environment and then construct their original knowledge. Based on the data, we could see teachers plays a dominant role in the translation teaching process. Besides, students think that teachers should be their friends in the teaching process so that they could interact with each other to solve the problems. And also teachers could arouse their interest in translation class. Therefore, teachers should create a proper environment to help students construct their knowledge.

\begin{tabular}{|l|l|l|}
\hline Question & Choice items & proportion \\
\hline $\begin{array}{l}\text { 2. In your translation class, the } \\
\text { teacher spend more time talking }\end{array}$ & Totally Agree & $55.0 \%$ \\
\cline { 2 - 3 } & Agree & $35.8 \%$ \\
\cline { 2 - 3 } & Not sure & $7.6 \%$ \\
\cline { 2 - 3 } & Disagree & $1.6 \%$ \\
\hline \multirow{2}{*}{$\begin{array}{l}\text { 9. The teacher chooses the } \\
\text { materials and determines the }\end{array}$} & Totally Agree & $19.6 \%$ \\
\cline { 2 - 3 } teaching process. & Agree & $59.0 \%$ \\
\cline { 2 - 3 } & Not sure & $5.10 \%$ \\
\cline { 2 - 3 } & Disagree & $13.2 \%$ \\
\hline \multirow{2}{*}{$\begin{array}{l}\text { 11. I am very interested in the } \\
\text { translation teaching with the help } \\
\text { of the teacher. }\end{array}$} & Totally Agree & $24.3 \%$ \\
\cline { 2 - 3 } & Agree & $54.2 \%$ \\
\cline { 2 - 3 } & Not sure & $19.4 \%$ \\
\cline { 2 - 3 } & Disagree & $2.06 \%$ \\
\cline { 2 - 3 } & Never & $0 \%$ \\
\hline
\end{tabular}

\section{B. Learners in Translation Teaching Process}

Learners play an important role in the translation learning, they are considered as the participants of the teaching activity. Question 12 aims to find out the status of the students' autonomous learning. According to the survey, $28.1 \%$ students think they like the autonomous learning very much, while $60.0 \%$ students show that they have not so much interest in the autonomous learning. $17.8 \%$ students learn translation knowledge with the help of the teacher; they lack the motivation of autonomous learning. 3.3\% students have never engaged in the autonomous learning.

From the data, we can observe that most students lack the abilities of autonomous learning in the translation learning.

According to the constructivist theory, learners could construct more knowledge under proper environment. In the process of English translation, students should stimulate the original linguistic knowledge to translate the source text. They should remedy their ideas in the discussion with other learners. What's more, students acquire the translation ability through observations and discussion. When we teachers give the feedback to the students, we'd better give them positive reaction so that they could enjoy the happiness of their fulfillment. If students have unilateral knowledge about the translation, they should be helped patiently to classify the problems. When they meet new problems in the translation teaching process, the answers could be received if they have enough evidence. Students should be encouraged to exhibit their originality and creativity .Only by this, the role of the teacher could be brought into full play.

\section{Teaching Content in Translation Teaching Process}

What are taught in the translation course is also important in the translation teaching process. Teachers could choose the proper teaching materials according to their needs, and it is necessary to monitor the whole teaching process.

We can observe from the proportion that, among the teaching materials, translation theories and the translation 
strategies are relatively small while the translation exercises occupy the big part of the chart.

\begin{tabular}{|l|l|l|}
\hline Question & Choice items & Attitude \\
\hline $\begin{array}{l}\text { 3. Do you think it is } \\
\text { helpful to show the } \\
\text { translation materials } \\
\text { by multi-media? }\end{array}$ & Very much & $38.8 \%$ \\
\cline { 2 - 3 } & Just so so & $47.4 \%$ \\
\cline { 2 - 3 } $\begin{array}{l}\text { 6. What is the reason } \\
\text { for your inefficient } \\
\text { translation learning? }\end{array}$ & $\begin{array}{l}\text { The translation material is } \\
\text { difficult }\end{array}$ & $12.4 \%$ \\
\cline { 2 - 3 } & Lack of autonomous learning & $19.3 \%$ \\
\cline { 2 - 3 } & $\begin{array}{l}\text { Without interaction in the } \\
\text { translation class }\end{array}$ & $23.9 \%$ \\
\cline { 2 - 3 } & $\begin{array}{l}\text { Translation strategies are } \\
\text { difficult to put into practice }\end{array}$ & $23.0 \%$ \\
\hline
\end{tabular}

\section{Environment in Translation Teaching Process}

Constructivists believe that learning could not happen in the isolated world. Environment will help the development of the cognition. Question 13 is to find out the status of the translation knowledge that students learn in the translation teaching process under the computer-assisted environment in figure 1

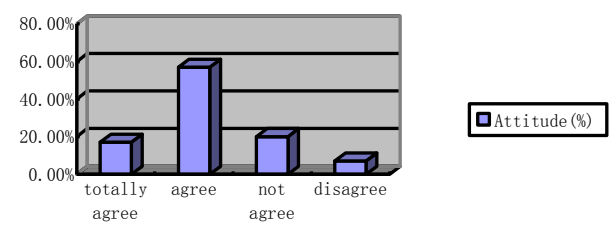

Figure 1. Status of translation knowledge

From the Figure above, we can see that most students regard they learn a lot of translation knowledge through the multi-media and the network. Constructivists say that learning happen in a certain environment. The effect of the condition in the environment on learning cannot be underestimated. Therefore, Constructivism proposes to cultivate the students' group awareness and the cooperative competence. In the teaching process, teachers should ask every student to involve in the discussion to communicate with each other. Through the cooperative learning, a good environment could be formed among students. In a word, it is necessary for students to be in a safe and happy environment through the communication between the students and teachers in the aspect of cognition and emotion. It seems that, under the multimedia and internet environment, it is much easier for students to communicate and cooperate with each other.

\section{E. Instruments in Translation Teaching Process}

Q14 and four extra questions aims to investigate the way students feed the problems to the teachers after the translation class, no feedback occupies $13.5 \%, 60.9 \%$ students ask questions by sending emails, while only $17.6 \%$ students ask the teacher until the next time.

The results show that most students think the multimedia and network should be background. And also students could send information to the teacher, and they can communicate with other through the Internet. By using this kind of teaching means, teachers could proficiently guide the students to do "Communication", "Conversation" and "Cooperation". All of these advantages could not be compared by other teaching means.

\section{F. Assessment}

According to the constructivist theory, in. the teaching and learning process, evaluation plays an important role to judge the effect of the translation course. Q17 aims to investigate how to evaluate the effect of the translation course. According to the statistics, examination occupies $25 \%$ in the assessment, while the attendance and assignment take a high proportion, i.e. $30 \%$ and $20 \%$ respectively. The students' performance only occupies $25 \%$ in the assessments. We could easily see a negligence of other element about the assessments, such as learning strategies and the attitudes towards the class.

In the course of reforming the education, it is necessary to carry out the proper methods to evaluate the translation teaching. Some scholars, in 2003, proposed that there are two ways to evaluate this course, formative assessment and summative assessment. As to translation teaching course, it is effective to combine these two methods to evaluate this course. The methods focused on not only the teaching in the classroom, but also how to let students gain the guidance from the teachers and have chances to discuss and communicate with the teachers in the course of translation teaching. Thus the teachers will give them immediate feedback. Besides, at the end of the semester, students had better receive the anonymous survey to collect the suggestion about the content and structure of this course from the students.

\section{SUGGESTIONS FOR COMPUTER APPLICATION IN CONSTRUCTIVIST TRANSLATION TEACHING MODE}

With the aim to utilize the multimedia and network into the translation teaching process based on the constructivist theory. This part proposes some suggestions to overcome the difficulties appeared in the above. The following points are based on some ideas proposed by Lin kenan in 2000.

\section{A. Cooperative Learning -Group Discussion.}

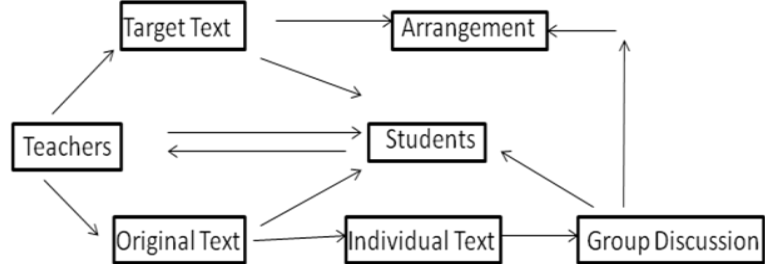

Figure 2. Learner-centered cooperative learning mode

In 1986, Johnson, D. W., Johnson, R. T. \& Holubec gave the definition for cooperative learning, which was to attain group goals that couldn't be obtained by working alone or competitively. Cooperative Learning emphasizes the spirit of the team, the group's success depend on each member's efforts in the team. According to the 
characteristics of the translation course, the learner-centered cooperative learning mode is designed as in Figure 2. Through this cooperative learning, students will grasp much useful translation knowledge. And they will have the sense of responsibility to solve the problem and help each other. As for the teacher, they could give the students feedback immediately through the internet without the limitation of the time and space. And also, they could summarize some typical mistakes according to the assignment written by each student. It is necessary to cultivate students' cooperative spirit and thus it is a necessity to adopt the cooperative learning teaching method.

\section{B. Autonomous Learning}

According to Phil Benson, autonomous learning is to hold and responsible for all the decisions concerning all aspects of learning such as (1) determining the objectives (2) defining the contents and processions (3) selecting methods and techniques to be used (4) monitoring the procedures of acquisition properly speaking(5) evaluating what has been acquired. According to the investigation in the last chapter, Q12 aims to investigate the students' attitudes toward the autonomous learning, $86.7 \%$ students' show that they like the autonomous learning,

Autonomous learning is necessary for the university students, since it will raise students' the ability to acquire the translation knowledge and the think independently and creatively. Students could autonomously choose the translation tasks. They translate the texts, and then discuss with other students through internet to modify the target text. After the discussion, the proper texts could be sent to the teacher through the Internet.

\section{The Change of Translation Teaching Mode}

1) Assisting translation teaching through internet: The translation course is a very complex and comprehensive course. After accumulating the translation knowledge, students need to practice a lot based on the theoretical knowledge and be guided by the qualified translation teacher. Also, students should possess the creative thinking ability and have a good relationship with other students. Through these ways, students' translation ability could be strenghened and cultivated. With the utilization of the Internet, these ways seem feasible and available. Teacher could complete the existed materials by using the internet and update the latest materials to satisfy students' needs..

2) Providing Relevant Context of Translation Materials: Establishing a vivid and comprehensive environment is necessary for students to leam the translation knowledge, which assists the translation teaching by utilization of the internet and the multimedia. In the course of translation, it is helpful for students to leam the function and background information of the source text with the help of the certain context so that they could choose the proper words and expressions.

\section{Teacher's Feedback Through Internet On Time}

Feedback, especially the effective feedback, is an important part in foreign language teaching. It cannot be ignored in improving quality of translation. During the process of teaching and learning under the multimedia and the internet, it is necessary for the teacher to give feedback to students, and also students need to response to the questions that the teachers have proposed in the translation course. However, with the limited time in class, students need to do a lot of practice after class. Therefore, students need to send the assignments to the teacher through e-mail or other tools. At the same time, teacher should give students the immediate feedback so that students could recognize the mistakes and correct them immediately. It is the best way for teacher to respond to the students without the barricade of the time and space. And also, students could avoid the embarrassment to meet the teacher. Students gain confidence to communicate with the teacher through the internet.

This paper proposes some implications on computerassisted translation teaching, but further researches are still needed to study how these implications are put into practice, and what effects will be achieved after the applications.

\section{REFERENCES}

[1] Benson P, Teaching and Researching Autonomy in Language Learning . Longman Publication Group, 2005, pp.48

[2] Gu Peiya \& FangYing, "Constractivist Project-based learning with Technology: An Implication Report," Foreign Language and Teaching, 2003, pp.7

[3] Huang Li, "Translation Teaching under the Guidance of Constructivism Theory," ShangHai Translator, 2011, pp.69-70

[4] Johnson, D. W., Johnson, R. T. \& Holubec, E. J., Circles of learning: Cooperation in the classroom. Edina, MN: Interaction Book Company,

[5] Shi Xinmi \& Xiao Weiqing, "Translation teaching with information technology - A new perspective of translation teaching,". Foreign Language World, 2006, pp.48-74

[6] Xu Bin, "Application of CAT in Teaching and Researching," ShangHai Translator, 2006, pp.59-60 